\title{
ANALISIS KESANTUNAN BERBAHASA MENURUT LEECH PADA TUTURAN BERBAHASA ARAB GURU PONDOK PESANTREN IBNUL QOYYIM PUTRA YOGYAKARTA TAHUNAJARAN 2016/2017 (KAJIAN PRAGMATIK)
}

\author{
Yeni Lailatul Wahidah \\ Hendriana Wijaya \\ e-mail: Yeni lailatulwahidah@yahoo.co.id \\ UIN Sunan Kalijaga Yogyakarta \\ Jln. Marsda Adi Sucipto Yogyakarta
}

\begin{abstract}
This research is aimed to find out the structure of Arabic speech that is used by the teacher and the politeness aspects of language in Arabic speech which is used by Ibnul Qoyyim Boarding School For Boys when teaching santri in classroom. This research is a qualitative research by collecting data by interacting with people in place of research. The method that researchers use in this study is divided into three namely the method of data provision, data analysis, and methods of data analysis results. After analyzing the direct speech by the subject teacher of Tamrin Lugah in Ibnul Qoyyim Boarding School For Boys with the theory of politeness of Geoffey Leech, it resulted in the tact maxim of 17 speeches, the generosity maxim of 4 speeches, the approbation maxim of 14 speeches, the agreement maxim of 25 speeches, and the sympathy maxim of 4 speeches. Whereas in practice the teacher also violated the language-assisted language with the tact maxim of 13 speeches, the approbation maxim of 2 speeches, and the aggrement maxim of 7 speeches, and researchers did not find the modesty maxim.
\end{abstract}

Keywords: institution, language politeness, teacher's speech

\section{PENDAHULUAN}

Bahasa merupakan sarana penting untukberkomunikasi antar manusia.Mereka memanfaatkan bahasa sebagai salah satu sarana untuk mengungkapkan pendapat, pikiran, dan idesebagaimana mereka menggunkannya untuk berkomunikasi dengan teman. Hal ini menunjukan bahwa pentingnya bahasa dalam komunikasi setiap orang, sehingga manusia sadar bahwa mereka adalah makhluk yang membutuhkan komunikasi dan bersosialisasi. Selain itu, dalam bersosialisai juga dituntut untuk bersikap santun dan sopan.

Kesantunan merupakan perilaku yang diekspresikan dengan cara yang baik atau beretika. Apa yang dianggap santun oleh suatu kultur, mungkin tidak demikian halnya dengan kultur yang lain (Zamzani, 2010: 2). Kesantunan merupakan fenomena kultural, sehingga dalam pesantren, guruguru perlu membina dan mendidik para santrinya berbahasa santun, sebab guru mempunyai peran penting dalam memberikan tauladan bagi santrinya, bila 
mereka tidak membiasakan berbahasa santun maka tidak mustahil bahasa santun yang sudah adapun bisa hilang dan lahir generasi yang arogan, kasar, dan kering dari nilai-nilai etika dan agama. Pengamatan sementara menunjukkan akibat dari ungkapan bahasa yang kasar, dan arogan sering kali menyebabkan perselisihan dan perkelahian di kalangan remaja. Sebaliknya, mereka yang terbiasa berbahasa santun dan sopan pada umumnya mampu berperan sebagai anggota masyarakat yang baik. Ucapan dan perilaku santun merupakan salah satu gambaran dari manusia yang utuh sebagaimana tersurat dalam tujuan pendidikan umum, yaitu manusia yang berkepribadian.

Kajian mengenai sebuah tuturan yang mempertimbangkan tentang bagaimana cara penutur mengatur apa yang ingin mereka katakan yang disesuaikan dengan siapa yang diajak bicara adalah kajian pragmatik. Pragmatik sangat terikat dengan konteks sehingga disini akan menjadi menarik jika kesantunan berbahasa guruketika mengajar di kelas dikaji menurut maksud penutur (guru) itu sendiri. Karena guru juga terdiri dari masyarakat yang pasti heterogen dan bahasa yang digunakan selalu menunjukan variasi internal sebagai akibat keberagaman latar belakang sosial budaya penuturnya. Sebagaimana yang disampaikan oleh Yule bahwa pragmatik adalah studi tentang makna yang disampaikan oleh penutur dan ditafsirkan pendengar (George Yule, 2006: $3)$.

Pondok pesantren merupakan lembaga yang banyak menggunakan bahasa Arab sebagai bahan pembelajaran, baik mengenai materi ruhiyah maupun untuk menunjang keahlian berbahasa Arab. Penggunaan bahasa Arab oleh guru di sejumlah pondok pesantren dimaksudkan agar membantu para santri dalam memahami materi-materi kajian berbahasa Arab dan juga menjadi aturan kurikulum pondok pesantren itu sendiri. Di samping itu, tidak sedikit juga dari pondok pesantren yang mengasah kemahiran berbahasa Arabnya dengan cara menggunakan bahasa Arab sebagai alat komunikasi atau percakapan sehari-harinya. Sebagai salah satu kemahiran berbahasa, kemahiran berbicara merupakan salah satu jenis kemampuan yang ingin dicapai dalam pengajaran bahasa modern termasuk bahasa Arab (Ahmad, 2005: 112). Dr. Mulyanto Sumardi menjabarkan bahwa tujuan mempelajari bahasa asing (termasuk bahasaArab) adalah agar seseorang dapat berkomunikasi dengan menggunakan bahasa tersebut, baik lisan ataupun tulisan dengan baik dan tepat (Mulyadi, 1974: 56).

Pondok Pesantren Ibnul Qoyyim Putra adalah pondok pesantren yang berdiri di bawah naungan Yayasan Persaudaraan Djamaah Haji Indonesia (PDHI). Pondok pesantren ini merupakan salah satu dari pondok pesantren-pondok pesantren yang menggunakan bahasa Arab sebagai bahasa resmi di kompleks pondok pesantren.Semua santri diharuskan menggunakan bahasa Arab dalam percakapan sehari-hari mereka dalam waktu 24 jam dalam sehari artinya santri harus bercakap menggunakan bahasa Arab seharian penuh sesuai dengan jadwal yang sudah ditentukan. Selain itu, seorang guru juga tidak kalah andilnya dalam berbahasa Arab ketika mengajar di kelas. Selain guru mengikuti aturan kurikulum untuk berbahasa Arab ketika mengajar 
santri-santrinya di kelas, guru juga diharapkan mampu bersikap baik dan sopan terhadap para santrinya dalam setiap tuturan yang diutarakan, sehingga sangat menarik jika dikaji dengan analisis pragmatik yaitu terkait dengan tuturan berbahasa Arab yang digunakan oleh guru ketika mengajar di dalam kelas yang ditinjau dari segi kesantunan berbahasanya. Penentuanguru sebagai objek kajian, mengingat guru lebih bersikap santun dan mampu bertutur dengan menggunakan bahasa Arab dibandingkan para santri yang masih pada tahap belajar. Berpijak dari pemaparan latar belakang di atas, penelitian ini akan membahas tentang kesantunan berbahasa yang dikemukakan oleh Leech, dan menjadikan tuturan bahasa Arab yang digunakan guru sebagai objek kajian. Peneliti perlu mengurai terkait rumusan masalah yang hendah dikaji yaitu struktur tuturan berbahasa Arab yang digunakan guru dan aspek kesantunan berbahasa pada tuturan berbahasa Arab yang digunakan guru.

\section{LANDASAN TEORI}

\section{Kesantunan Berbahasa}

Kesantunan berbahasa terdapat sejumlah linguis berpendapat, terutama terkait dengan skala kesantunan berbahasa, misalnya Leech, Brown-Levinson. Kesantunan Berbahasa Menurut Leech (1) cost-benefit scale (skala ini mengacu pada besar kecilnya kerugian dan keuntungan yang diakibatkan oleh sebuah tindak tutur. Semakin merugikan dampak tuturan itu bagi penutur, tuturan itu dianggap semakin santun. Begitu pula sebaliknya), (2) optionality scale (skala ini mengacu pada banyak sedikitnya alternatif pilihan yang disampaikan penutur), (3) indirectness scale (skala ini mengacu pada langsung atau tidaknya suatu maksud dikemukakan. Tuturan dianggap sopan bila disampaikan tidak secara langsung), (4) authority scale (skala ini mengacu pada hubungan status sosial antara penutur dan petutur), dan (5) social distance scale (skala ini mengacu pada hubungan sosial antara penutur dan penutur yang terlibat dalam pertuturan (Leech, 1993: 123-125).

\section{Prinsip Kesantunan Leech}

Maksim merupakan kaidah kebahasaan di dalam interaksi lingual; kaidah-kaidah yang mengatur tindakannya, penggunaan bahasanya, dan interpretasi-interpretasinya terhadap tindakan dan ucapan lawan tuturnya. Selain itu maksim juga disebut sebagai bentuk pragmatik berdasarkan prinsip kerja sama dan prinsip kesopanan. Maksim-maksim tersebut menganjurkan agar kita mengungkapkan keyakinankeyakinan dengan sopan dan menghindari ujaran yang tidak sopan.

Berbahasa yang baik tentunya harus mengikuti aturan-aturan yang ada.Hal tersebut supaya setiap tuturan yang diutarakan dapat menghasilkan bahasa yang santun. Leech menyatakan bahwa "Seseorang dapat dikatakan sudah memiliki kesantunan berbahasa jika sudah dapat memenuhi prinsip-prinsip kesantunan yang dijabarkan menjadi maksim (ketentuan/ajaran). (Kunjana, 2005: 59-66), yaitu: 


\section{Maksim Kebijaksanaan (Tact Maxim)}

Maksim kebijaksanaan yaitu maksim yang menggariskan bahwa setiap peserta pertuturan hendaknya berpegang pada prinsip untuk selalu mengurangi keuntungan dirinya sendiri dan memaksimalkan keuntungan pihak lain dalam kegiatan bertutur. Orang bertutur yang berpegang dan melaksanakan maksim kebijaksanaan akan dapat dikatakan sebagai orang santun. Jika dalam bertutur, seseorang berpegang pada maksim kebijaksanaan, ia dapat menghindarkan sikap dengki, iri hati, dan sikap yang kurang santun terhadap mitra tutur.

Contoh :

Tuan rumah : "Silakan makan saja dulu, nak! Kami semua sudah mendahului".

Tamu : "Wah, saya jadi tidak enak, Bu".

Di dalam tuturan di atas tampak jelas bahwa apa yang dituturkan oleh tuan rumah sangat memaksimalkan keuntungan bagi tamu. Bahkan, sering kali ditemukan minuman dan makanan yang disajikan kepada tamu diupayakan agar layak diterima dan dinikmati oleh tamu tersebut.

\section{Maksim Kedermawanan (Generosity Maxim)}

Maksim kedermawanan yaitu maksim kemurahan hati, yang mengharuskan peserta tutur untuk menghormati rang lain. Penghormatan tersebut terjadi jika peserta tutur dapat meminimalkan keuntungan bagi dirinya dan memaksimalkan keuntungan bagi pihak lain.

Contoh :
Anak kos A : "Mari, saya cucikan baju kotormu! Pakaianku tidak banyak kok yang kotor".

Anak kos B : "Tidak usah, Mbak. Nanti siang saya akan mencuci juga kok"

Di dalam tuturan di atas, dapat dilihat dengan jelas bahwa si A berusaha memaksimalkan keuntungan pihak lain dengan cara menawarkan bantuan untuk mencucikan pakaian kotor si B. Hal tersebut merupakan realisasi maksim kedermawanan atau kemurahan hati dalam bermasyarakat.

Maksim Penghargaan (Approbation Maxim) Maksim penghargaan yaitu maksim yang membuat orang akan dapat dianggap santun apabila dalam bertutur selalu berusaha memberikan penghargaan kepada pihak lain. Sehingga, para peserta tutur tidak saling mengejek atau merendahkan pihak lain.

Contoh :

Dosen A : "Pak, tadi saya sudah memulai kuliah perdana dengan materi puisi".

Dosen B : "Oya, tadi saya mendengar pembacaan puisinya jelas sekali".

Dalam pertuturan di atas, pemberitahuan yang disampaikan dosen A terhadap rekannya dosen $B$ ditanggapi dengan sangat baik, bahkan disertai pujian atau penghargaan oleh dosen B. Maka, dalam pertuturan itu dosen B berperilaku santun terhadap dosen A.

Maksim Kesederhanaan (Modesty Maxim)

Maksim Kesederhanaan atau maksim kerendahan hati, yaitu maksim yang mengharapkan peserta tutur dapat bersikap 
rendah hati dengan cara mengurangi pujian terhadap dirinya sendiri.

Contoh :

Ibu A : "Nanti Ibu yang memberi sambutan ya, dalam rapat PPK".

Ibu B : "Waduh... nanti grogi saya".

Pernyataan di atas, merupakan tuturan antara Ibu PPK ketika akan mengadakan rapat. Ibu A menunjukkan kerendahan hati kepada Ibu B, dengan memintanya menjadi orang yang memberikan sambutan dalam rapat dan bukan dirinya, karena orang akan dikatakan sombong apabila di dalam kegiatan bertutur selalu mengunggulkan dirinya sendiri.

\section{Maksim Permufakatan (Agreement Maxim)}

Maksim permufakatan atau maksim kecocokan, yaitu maksim yang mengharuskan para peserta tutur dapat saling membina kococokan di dalam kegiatan bertutur.Jika terdapat kecocokan antara keduanya, maka mereka dapat dikatakan bersikap santun.

Contoh :

Guru A : "Ruangannya gelap ya, Bu!"

Guru B : "He...eh! Saklarnya mana ya?"

Pernyataan di atas, merupakan tuturan seorang guru kepada rekannya pada saat mereka berada di ruang guru. Ketika guru A menyatakan ruangannya gelap, respon guru $\mathrm{B}$ dengan menanyakan mana saklarnya menunjukkan bahwa guru $\mathrm{A}$ dan guru $\mathrm{B}$ memiliki kecocokan.

Maksim Kesimpatisan (Sympath Maxim),

Maksim kesimpatisan yaitu maksim yang mengharapkan peserta tutur dapat memaksimalkan sikap simpati antara pihak yang satu dengan pihak yang lain.

Contoh :

Ani : "Tut, nenekku meninggal."

Tuti :'Innalillahiwainnailaihi rajiun. Aku ikut berduka cita."

Pernyataan di atas merupakan tuturan seorang karyawan kepada rekannya yang memiliki hubungan erat saat mereka berada di ruang kerja.Pernyataan Ani yang memberitahukan kalau neneknya meninggal mendapat simpati dari Tuti rekan kerjanya dengan ikut berduka cita atas meninggalnya nenek Ani.

\section{METODE PENELITIAN}

Dilihat dari jenisnya, penelitian ini adalah penelitian kualitatif. Menurut Mc Millan dan Schumarcer sebagaimana yang dikutip oleh Syamsuddin AR, bahwa penelitian kualitatif adalah suatu pendekatan yang juga disebut pendekatan investigasi kerena biasanya peneliti mengumpulkan data dengan cara berinteraksi dengan orang di tempat penelitian (Syamsuddin, dkk, 2009: 73). Metode yang peneliti gunakan dalam penelitian ini dibagi menjadi tiga yaitu metode penyediaan data, analisis data, dan metode hasil analisis data.

Metode Penjaringan data

Tahap penjaringan data merupakan upaya peneliti menyediakan data guru Pondok Pesantren Ibnul Qoyyim Putra pada tahun pelajaran 2016/2017. Data tersebut dipahami sebagai fenomena lingual khusus yang mengandung dan berkaitan langsung 
dengan masalah yang dimaksud. Data yang demikian itu, substansinya dipandang berkualifikasi valid atau sahih dan reliable atau terandal. Upaya penyediaan data itu semata-mata untuk dan demi kepentingan analisis (Sudaryanto, 1993:56). Jika dilihat dari data yang ada, penelitian ini termasuk peneltian kualitatif, sebagaimana pernyataan Mc Millan dan Schumarcer yang dikutip oleh Syamsuddin AR di atas. Data yang ingin peneliti kumpulkan dengan menggunakan metode observasi dan wawancara (interview). Metode Observasi yaitu mencari data dengan cara menyimak tuturan guru secara langsung di kelas, sehingga data yang dihasilkan benar-benar fakta dan akurat. Target observasi peneliti yaitu guruPondok Pesantren Ibnul Qoyyim Putra. Sedangkan metode wawancara (interview) yang peneliti lakukan yaitu melakukan tanya jawab dengan beberapa narasumber terkait. Narasumber yaitu guru bersangkutan, dimana beliaulah sebagai penutur secara langsung di kelas dan menjadi target observasi peneliti. Guruadalah sumber terpenting dalam mendapatkan data yang diinginkan, karena tuturan guru yang menjadi pusat penelitian ini. Pencarian data ini diperoleh dengan mendengarkan tuturan mereka secara langsung, mencatat tuturan mereka, dan melakukan interview dengan guru terkait. Ini diakui peneliti sebagai sumber data yang merupakan penentuan subyek penelitian. Suharismi Arikuto menjelaskan penentuan subyek penelitian adalah orang atau apa saja yang menjadi subyek penelitian (Suharismi, 1989: 40).

Metode Analisis Data
Masuk pada metode analisis data, peneliti menganalisis data dengan teori kesantunan berbahasa kajian pragmatik. Penanganan tersebut muncul dari adanya tindakan mengamati, membedah atau mengurai dan memburaikan atau memorakkan masalah yang bersangkutan dengan cara-cara khas. Cara-cara khas tertentu yang ditempuh peneliti untuk memahami problematik satuan kebahasaan yang diangkat sebagai objek penelitian, itulahyang disebut metode analisis (Mastoyo, 2007: 49). Kemudian, peneliti menganalisis data tersebut melalui tiga langkah.

Adapun tahap-tahap yang akan peneliti lakukan untuk menganalisis yaitu:

a. Tahap Penyajian Data

Tahap menyajikan kalimat tuturan yaitu menunjukan data atau tuturan bahasa Arab yang digunakan guru mata pelajaran tamrin al-lughah.

b. Tahap Menerjemahkan

Pada tahap ini, peneliti mengartikan data tersebut ke dalam Bahasa Indonesia sesuai maksud dari penutur.Ini untuk memudahkan peneliti dalam menganalisis pada tahap selanjutnya.

c. Tahap Mendeskripsikan Tuturan

Peneliti memberikan gambaran dan menjelaskan tentang tuturan yang digunakan guru dengan teori kesantunan berbahasa menurut Leech dalam kajian pragmatik.

d. Tahap Mengklasifikasi data

Pada tahap akhir analisis ini, peneliti mengklasifikasi data yang sudah dideskripsikan pada tahap sebelumnya, yaitu mengelompokan 
tuturan-tuturan guru sesuai prinsip kesantunan berbahasa menurut Leech.

Penyajian Hasil Analisis Data

Pada tahap penyajian hasil analisis, sistematika yang digunakan adalah menggunakan penyajian informal yang merujuk pada metode penyajian hasil analisis oleh Sudaryanto. Metode penyajian informal adalah perumusan dengan kata atau kalimat biasa tanpa menggunakan tanda dan lambanglambang tertentu yang biasanya bersifat matematis (Sudaryanto, 1993: 145). Walaupun penyajian yang dilakukan ini dengan menggunakan kata-kata biasa, tetapi penyajian ini tetap memiliki terminilogi yang bersifat teknis. Penyajian informal digunakan dalam penelitian ini, karena metode tersebut memungkinkan penjelasan mengenai suatu kaidah secara detail, rinci, dan terurai sehingga dapat memberikan nilai keterbacaan yang tinggi dari hasil penelitian yang dilakukan. Metode penyajian informal digunakan dalam penelitian deskriptif kualitatif. Kemudian hasil yang didapatkan dan permasalahan yang ditemukan dari data tersebut bisa menjadi bahan untuk memberikan saran kepada pihak pondok pesantren Ibnul Qoyyim Putra.

\section{HASIL DAN PEMBAHASAN}

Pada tahap ini, peneliti akan memaparkan data hasil observasi yang telah peneliti lakukan sebelumnya. Objek observasi peneliti yaitu tuturan guru mata pelajarantamrin lughah ketika kegiatan belajar mengajar di
kelas.Setelah itu peneliti melakukan analisis dari data yang telah diperoleh dan telah dipaparkan pada data hasil penelitian. Kemudian dari pada itu, peneliti melakukan beberapa tahapan untuk menganalisis data-data tersebut. Adapun tahap yang dimaksud sebagai berikut:

$$
\text { السالام عليكم ورحة الله وبر كاته }
$$

Artinya: Semoga Allah melimpahkan keselamatan, rahmat, dan berkah kepada kalian

Deskripsi: Tuturan tersebut mempunyai makna guru memberikan salam dan sapaan kepada santri. Di di dalamnya juga terkandung doa yang diucapkan kepada santrinya.

Tuturan ini sangat jelas bahwa tuturan guru ini memaksimalkan keuntungan bagi santrinya (lawan tutur)

Klasifikasi: Maksim kebijaksanaan

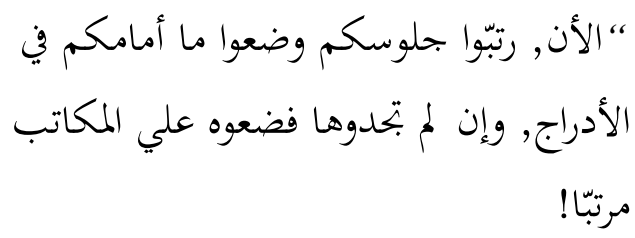

Artinya : Sekarang tertikanlah duduk kalian dan letakkanlah apapun yang ada di depan kalian di laci. Jika kalian tidak menemukan itu maka letakkanlah di atas meja dengan rapi!

Deskripsi: Tuturan tersebut mempunyai makna seorang guru memberikan perintah kepada santri untuk menertibkan duduk mereka dan juga merapikan buku dan perlengkapannya yang diatas meja. Dan perintah guru untuk meletakkannya di laci, tetapi jika tidak 
ada tidak mengapa untuk meletakkan di atas meja dengan rapi.

Tuturan ini menggambarkan bahwa guru memberikan intruksi kepada semua santi.Padahal, pada waktu tersebut beberapa santri sudah menertibkan duduk dan juga sudah merapikan perlatan sekolah mereka.Sehingga guru cenderung tidak maau untuk member perintah kepada santri satu persati, maka lebih mudah untuk langsung semuanya.

Klasifikasi: Pelanggaran maksim kebijaksanaan

$$
\text { طيّب, ماذا درسنا الآن؟ }
$$

Artinya : Baik. Apa pelajaran kita hari ini?

Deskripsi: Tuturan tersebut mempunyai makna bahwa guru memberi pertanyaan kepada santrinya terkait nama mata pelajara yang sedang dipelajari. Hal ini juga termasuk strategi guru supaya santri teringat dan fokus dengan mata pelajaran terkait.

Tuturan ini menunjukkan bahwa tuturan guru ini menginginkan respon dari santri. Jika dilihat dari jawaban santri, maka terlihat ada kecocokannya. Klasifikasi: Maksim permufakatan atau maksim kecocokan.

$$
\begin{aligned}
& \text { نعم, قبل أن أشرح لكم درسا جديدا, أريد أن } \\
& \text { أبين شيئا: للجسم أعضاء, منها:الرأس, والعين, } \\
& \text { واليد, والرجل, وغيرها }
\end{aligned}
$$

Artinya : Iya. Sebelum saya menjelaskan materi pelajaran yang baru, saya ingin menjelaskan suatu hal, badan memiliki anggota anataranya: kepala, tangan, kaki, dan lainnya.

Deskripsi: Tuturantersebut mempunyai makna bahwa guru mengajak santri untuk menyebutkan bersama terkait nama mata pelajaran yang sedang dipelajari. Hal ini juga termasuk strategi guru supaya santri siap dan fokus dengan mata pelajaran terkait.

Tuturan ini menunjukkan bahwa tuturan guru ini menginginkan respon dari santri. Jika dilihat dari jawaban santri, maka terlihat adanya kecocokan antara guru dan santri.

Klasifikasi: Maksim permufakatan atau maksim kecocokan.

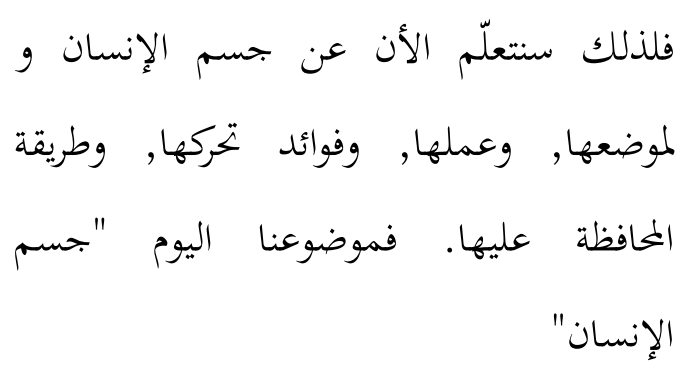

Artinya : Oleh karena itu, sekarang kita akan belajar tentang anggota badan manusia, letak, fungsi, dan manfaat gerakannya serta cara menjaganya. Maka, judul (pelajaran) kita hari ini adalah badan manusia.

Deskripsi: Tuturan tersebut menjelaskan bahwa guru memberikan kalimat pengantar sebelum menyebutkan judul materi yang akan dipelajari bersama para santrinya. Dan setelah itu guru menyebutkan judul terkait materi yang akan disampaikan. Tuturan ini mempunyai maksud supaya santri lebih mudah memahami materi 
dan tau gambaran materi yang akan dipelajari .

Klasifikasi: Maksim kebijaksanaan.

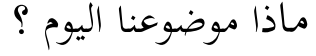

Artinya : Apa judul (pelajaran) kita hari ini?

Deskripsi: Tuturan tersebut menjelaskan bahwa guru melontarkan pertanyaan kepada santrinya terkait judul pelajaran yang akan dipelajarinya. Tuturan ini menunjukkan bahwa tuturan guru menginginkan respon dari santri. Jika dilihat dari jawaban santri, maka terlihat adanya kecocokan antara guru dan santri.

Klasifikasi: Maksim permufakatan atau maksim kecocokan.

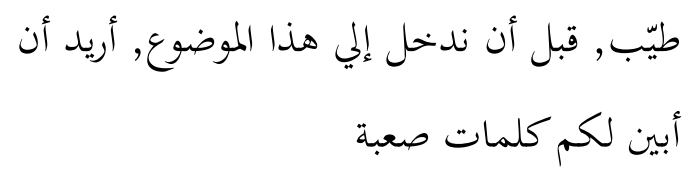

Artinya : Baik, sebelum memasuki (mempelajari) judul ini, saya ingin menjelaskan kata-kata yang sulit terlebih .

Deskripsi:Tuturan tersebut mempunyai maksud bahwa guru sebelum memulai materi yang akan dipelajari bersama, guru terlebih dahulu membahasa kosakata yang suli supaya nantinya lebih mudah memahami materi yang akan dibahas.

Tuturan ini dapat disimpukan bahwa guru memudahkan santri sebelum melakukan pembelajaran lebih lanjut. Klasifikasi: Maksim kebijaksanaan.

$$
\text { الكلمة الأولى: الرَّس, قولوا: الرّأس ! }
$$

Artinya : Kata pertama: al-ra'su (kepala). Ucapkan “al-ra'su” (kepala)!

Deskripsi: Tuturan tersebut mempunyai makna santri diharapkan mengetahui kosakata yang sukar sebelum memasuki materi lebih dalam.

Tuturan ini bermaksud mengharap respon santri untuk melaksanakan intruksi dari sang guru dan pada kenyataannya para santripun merespon dan mengikuti sang guru.

Klasifikasi: Maksim permufakatan atau maksim kecocokan.

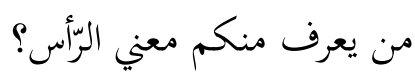

Artinya : Siapa yang tahu arti "alra'su'.

Deskripsi: Tuturan tersebut menyatakan bahwa sang guru bertanya terkait arti dari kosa kata yang akan dibahas nantinya. Sang guru juga berkeinginan pertanyaannya dijawab oleh santrinya.

Tuturan sang guru tersebut yang berupa pertanyaan akhirnya direspon santri dengan jawaban yang sesuai, sehingga ada kecocokan antar kedua tuturan.

Klasifikasi: Maksim permufakatan atau maksim kecocokan.

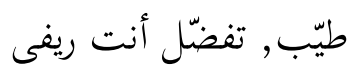

Artinya : Baik, silakan (untuk menjawab) Refi.

Deskripsi: Tuturan tersebut mempunyai makna bahwa guru mempersilahkan 
santri yang mengajukan dirinya untuk menjawab. Dan sang guru mempersilakan untuk menjawab. Hal ini sang guru juga mempunyai harapan kepada santri (Refi) untuk menjawab. Tuturan ini direspon oleh santri bersangkuan dan dijawab denga baik. Klasifikasi: Maksim permufakatan atau maksim kecocokan.

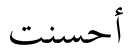

Artinya : Kamu benar.

Deskripsi:Tuturan tersebut menunjukkan bahwa sang guru memberikan apresiasi kepada santrinya yang sudah menjawab pertanyaan. Tuturan ini juga mengandung sebuah penghargaan kepada santri tersebut. Klasifikasi: Maksim penghargaan.

$$
\text { الكلمة الثانية: العنق, قولوا: العنق ! }
$$

Artinya : Kata kedua: al-'unuqu (leher). Ucapkan "al-'unuqu“ (leher) Deskripsi: Tuturan tersebut mempunyai makna santri diharapkan mengetahui kosakata yang sukar ini sebelum memasuki materi lebih dalam. Kemudian guru memberikan intruksi untuk mengucapkan kosa kata tersebut. Tuturan ini menadapat respon baik oleh para santri dengan mengucapkan kosakata tersebut, sehingga terlihat jelas adanya kecocokan antar kedua pihak.

Klasifikasi: Maksim permufakatan atau maksim kecocokan.

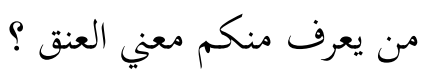

Artinya : Siapa yang tahu arti "al'ипиqu".

Deskripsi: Tuturan tersebut menyatakan bahwa sang guru bertanya terkait arti dari kosa kata yang kedua yang akan dibahas nantinya. Sang guru juga berkeinginan pertanyaannya dijawab oleh santrinya.

Tuturan sang guru tersebut yang berupa pertanyaan akhirnya direspon santri dengan jawaban yang sesuai, sehingga ada kecocokan antar kedua tuturan.

Klasifikasi: Maksim permufakatan atau maksim kecocokan.

$$
\text { نعم, تفضّل أنت يا فيرى! }
$$

Artinya : Iya, silakan kamu (untuk menjawab) Feri

Deskripsi: Tuturan tersebut mempunyai makna bahwa guru mempersilahkan santri bernama Feri yang mengajukan dirinya untuk menjawab. Hal ini sang guru juga mempunyai harapan kepada santri (Feri) untuk menjawab dengan sesuai.

Tuturan ini direspon oleh santri bersangkuan dan dijawab dengan baik, sehingga di dalam tuturan guru dan santri terdapat kecocokan.

Klasifikasi: Maksim permufakatan atau maksim kecocokan.

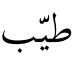

Artinya : Baik/bagus.

Deskripsi: Tuturan tersebut menunjukkan bahwa sang guru memberikan apresiasi kepada santrinya 
yang sudah menjawab pertanyaan. Tuturan ini juga mengandung sebuah penghargaan kepada santri tersebut.

Klasifikasi: Maksim penghargaan.

$$
\text { أضعها في جملة مفيدة: العنق تحت الرّأس }
$$

Artinya : Saya meletakkan kosakata tersebut pada kalimat sempurna: al'unuqu tahta al-ra's (Leher berada di bawah kepala).

Deskripsi: Tuturan tersebut mempunyai maksud bahwa guru memberi contoh sebuah kalimat dengan menggunakan kosakata yang akan dipelajari. Contoh tersebut juga menggunakan bahasa Arab sehingga santri benar-benar faham walau menggunakan bahasa Arab.

Tuturan ini dapat disimpukan bahwa guru ingin lebih memudahkan santri dalam memahami kosa kata tersebut. Klasifikasi: Maksim kebijaksanaan.

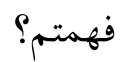

Artinya : (Apakah) kalian faham?

Deskripsi: Tuturan tersebut mempunyai makna sang guru memberikan pertanyaan kepada para santri perihal sudah memahami atau belum terkait contoh yang sudah diberikan oleh guru. Setelah pertanyaan tersebut, santri menjawab "na'am na'am" yang berarti para santri telah memahami.

Tuturan ini mendapat respon baik oleh para santri dengan merespon pertanyaan dari sang guru, sehingga guru dan santri terjadi sebuah kesamaan maksud.

Klasifikasi: Maksim permufakatan atau maksim kecocokan.

$$
\text { و الأن الكلمة الثالثة: اليد, قولوا: اليد ! }
$$

Artinya : Sekarang kalimat yang ketiga: "al-yadu" (tangan), ucapkan "al-yadu" (tangan).

Deskripsi: Tuturan tersebut mempunyai makna santri diharapkan mengetahui kosakata yang sukar ini sebelum memasuki materi lebih dalam. Kemudian guru memberikan intruksi untuk mengucapkan kosa kata tersebut Tuturan ini mendapat respon baik oleh para santri dengan mengucapkan kosakata tersebut, sehingga terlihat jelas adanya kecocokan antar kedua pihak.

Klasifikasi: Maksim permufakatan atau maksim kecocokan.

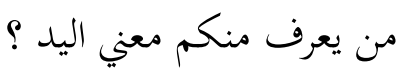

Artinya : Siapa yang tahu arti "alyadu"

Deskripsi: Tuturan tersebut menyatakan bahwa sang guru bertanya terkait arti dari kosa kata yang akan dibahas nantinya. Sang guru juga berkeinginan pertanyaannya dijawab oleh santrinya. Tuturan sang guru tersebut yang berupa pertanyaan akhirnya direspon santri dengan jawaban yang sesuai, sehingga ada kecocokan antar kedua tuturan. Klasifikasi: Maksim permufakatan atau maksim kecocokan. 


$$
\text { نعم, تفضّل أنت يا غاليه }
$$

Artinya : Iya, silakan (untuk menjawab) Galih

Deskripsi: Tuturan tersebut mempunyai makna bahwa guru mempersilahkan santri bernama Galih yang mengajukan dirinya untuk menjawab. Hal ini sang guru juga mempunyai harapan kepada santri (Galih) untuk menjawab dengan sesuai.

Tuturan ini yang kemudian direspon oleh santri bersangkuan dan dijawab dengan baik, sehingga di dalam tuturan guru dan santri terdapat kesesuaian maksud.

Klasifikasi: Maksim permufakatan atau maksim kecocokan.

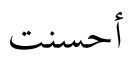

Artinya : Kamu benar.

Deskripsi: Tuturan tersebut menunjukkan bahwa sang guru memberikan apresiasi kepada santrinya yang sudah menjawab pertanyaan. Tuturan ini juga mengandung sebuah penghargaan kepada santri tersebut. Klasifikasi: Maksim penghargaan.

$$
\text { الكلمة الرابع: الصدر , قولوا: الصدر ! }
$$

Artinya: Sekarang kalimat yang keempat: الصدر "(dada), ucapkan "(dada).
Deskripsi: Tuturan tersebut mempunyai makna santri diharapkan mengetahui kosakata yang sukar tersebut sebelum memasuki materi lebih dalam. Kemudian guru memberikan intruksi untuk mengucapkan kosa kata terkait. Tuturan ini mendapat respon baik oleh para santri dengan mengucapkan kosakata tersebut, sehingga terlihat jelas adanya kesesuaian antar kedua pihak.

Klasifikasi: Maksim permufakatan atau maksim kecocokan.

$$
\text { أنت يا حسن قل: الصدر ! }
$$

Artinya : Kamu (yang bernama) Hasan, ucapkanlah "al-sadru”.

Deskripsi: Tuturan tersebut mempunyai makna santri diharapkan mengetahui kosakata yang sukar tersebut sebelum memasuki materi lebih dalam. Kemudian guru memberikan intruksi untuk mengucapkan kosa kata terkait. Akan tetapi, intruksi tersebut cenderung kurang sopan karena menggunakan kalimat yang terlalu pendek, sehingga cenderung kasar

Klasifikasi: Pelanggaran maksim kebijaksanaan

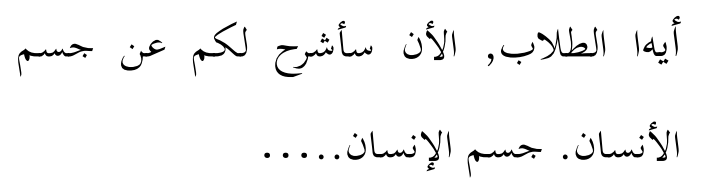

Artinya : Wahai santri, sekarang saya akan menjelaskan kepada kalian terkait 
(materi pelajaran berjudul) badan manusia .

Deskripsi: Tuturan tersebut mempunyai maksud bahwa guru akan menjelaskan kepada para santri tentang hal-hal terkait dengan materi yang dipelajari yaitu anggota badan manusia, baik dari segi nama, letak, fungsi dan manfaatnya.

Tuturan ini mempunyai maksud bahwa guru memaksimalkan kerugian untuk orang lain.

Klasifikasi: Maksim kedermawanan.

$$
\begin{array}{r}
\text { أريد أن يقرأ واحدا منكم المقالة والآخرون } \\
\text { يسمعون جيدا, أنت يا نوفل تفضل! }
\end{array}
$$

Artinya : Saya ingin salah satu dari kalian untuk membaca teks (materi pelajaran) sedangkan yang lain untuk mendengarkan. Kamu (yang bernama) Naufal silakan!.

Deskripsi: Tuturan tersebut mempunyai makna bahwa guru ingin mendengarkan bacaan santri terkait dengan materi. Akan tetapi, intruksi tersebut hanya di ditujukan kepada salah satu santri tanpa ada kerelaan mengangkat tangan, sehingga santri yang ditunjuk merasa sedikit kaget

Tuturan ini mempunyai arti bahwa guru memaksimalkan keinginannya dengan menunjuk salah satu santri untuk mengikuti perintahnya

Klasifikasi: Pelanggaran maksim kebijaksanaan
Artinya : Cukup.

Deskripsi: Tuturan tersebut menjelaskan bahwa guru meminta santri yang ditunjuk untuk membaca teks materi pelajaran. Akan tetapi, sang guru tidak memberikan apresiasi yang bagus kepada santri tersebut yaitu hanya dengan ucapan "cukup".

Klasifikasi: Pelanggaran maksim penghargaan.

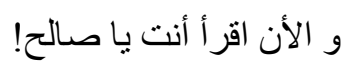

Artinya : Sekarang baca kamu (yang bernama) Sholeh

Deskripsi: Tuturan tersebut mempunyai makna santri diharapkan membaca materi yang dipelajari. Kemudian guru menunjuk Sholeh dan memberikan intruksi untuk membaca teks materi pelajaran terkait.Akan tetapi, intruksi tersebut cenderung kurang sopan karena menggunakan kalimat perintah terlalu pendek, sehingga cenderung kasar.

Klasifikasi: Pelanggaran maksim kebijaksanaan.

يكفيك

Artinya : Cukup.

Deskripsi: Tuturan tersebut menjelaskan bahwa guru meminta santri yang ditunjuk untuk membaca teks materi pelajaran. Akan tetapi, sang guru tidak memberikan apresiasi yang bagus kepada santri tersebut yaitu hanya dengan ucapan "cukup".

Klasifikasi: Pelanggaran maksim penghargaan.

أقر أ لكم كثف الخضور ومن يذكر اسمه فليرفع يده! 
Artinya : Saya bacakan daftar hadir. Dan yang disebut namanya untuk mengangkattangannya.

Deskripsi: Tuturan tersebut menjelaskan bahwa guru hendak membacakan daftar kehadiran santri. Hal ini bertujuan supaya santri bias dipastikan mengikuti semua kegiatan belajar ini.

Tuturan ini juga mempunyai maksud guru yang mengurangi keuntungan diri sendiri dengan mengecekkan kehadiran para santri.

Klasifikasi: Maksim kedermawanan.

$$
\text { و السلام عليكم وحمة الله وبر كاته }
$$

Artinya : Semoga Allah melimpahkan keselamatan, rahmat, dan berkah kepada kalian.

Deskripsi: Tuturan tersebut mempunyai makna guru memberikan salam kepada santri sebelum pembelajaran berakhir. Didalamnya juga terkandung doa yang diucapkan kepada santrinya.

Tuturan ini sangat jelas bahwa tuturan guru ini memaksimalkan keuntungan bagi santrinya (lawan tutur).

Klasifikasi: Maksim kebijaksanaan.

Pada pembahasan ini, peneliti telah melakukan analisis terkait dengan data yang sudah diperoleh sebelumnya.Data yang peneliti kumpulkan sebanyak 87 tuturan yang diucapkan guru ketika mengajar santri di kelas.Kemudian peneliti mengambil sebuah kesimpulan terkait analisis tersebut. Adapun hasil analisis tuturan guru pondok pesantren sebagai pengajar mata pelajaran Tamrin Lugah menunjukkan bahwa guru terkait mengikuti teori kesantuna berbahasa dengan maksim kebijaksanaan sejumlah 17 tuturan, maksim kedermawanan sejumlah 4 tuturan, maksim penghargaan sejumlah 14 tuturan, maksim kemufakatan sejumlah 25 tuturan, dan maksim kesimpatisan sejumlah 4 tuturan. Sedangkan pada praktek mengajar guru tersebut juga melakukan pelanggaran kesantuan berbahasa dengan maksim kebijaksanaan sejumlah 13 tuturan, maksim penghargaan sejumlah 2 tuturan, dan pelanggaran maksim kemufakatan sejumlah 7 tuturan, dan untuk maksim kesederhanaan peneliti tidak menemukannya.

\section{SIMPULAN DAN SARAN}

Setelah melakukan analisis terhadap tuturan langsung oleh guru mata pelajaran Tamrin Lugah Pondok Pesntren Ibnul Qoyyim Putra dengan teori kesantunan Geoffey Leech, maka dihasilkan maksim kebijaksanaan sejumlah 17 tuturan, maksim kedermawanan sejumlah 4 tuturan, maksim penghargaan sejumlah 14 tuturan, maksim kemufakatan sejumlah 25 tuturan, dan maksim kesimpatisan sejumlah 4 tuturan. Sedangkan pada praktek mengajar guru tersebut juga melakukan pelanggaran kesantuan berbahasa dengan maksim kebijaksanaan sejumlah 13 tuturan, maksim penghargaan sejumlah 2 tuturan, dan pelanggaran maksim kemufakatan sejumlah 7 tuturan, dan 
untuk maksim kesederhanaan peneliti tidak menemukannya.

Sesuai dengan hasil yang telah dianalisis,menunjukkan bahwa guru mata pelajaran Tamrin Lugah Pondok Pesntren Ibnul Qoyyim Putra masih harus meningkatkan prinsip kesantunan berbahasa sehingga praktek pembelajaran di kelas terasa lebih nyaman.Karena dari hasil analisis juga masih terlihat pelanggaran prinsip kesantunan berbahasa yang cenderung tidak berkesan sopan. Semoga saran ini bisa diambil manfaatnya oleh pihak Pondok Pesntren Ibnul Qoyyim Putra sebagai sebuah perubahan menjadi lebih baik.Bagi peneliti selanjutnya, diharapkan penelitian ini bisa menjadi acuan penelitian lanjutan dengan mengkaji aspek-aspek lain yang lebih rinci.Dan yang terakhir semoga bisa bermanfaat untuk semua kalangan yang membaca karya ini.

\section{DAFTAR PUSTAKA}

Arikunto, Suharsimi. 1989. Prosedur Penelitian: Suatu Pendekatan Praktis Jakarta: Bina Aksara.

Effendi, Ahmad Fuad. 2005. Metodologi Pengajaran Bahasa Arab. Malang: Misykat.

Kesuma, Tri Mastoyo Jati. 2007. Pengantar Metode Penelitian Bahasa. Yogyakarta: Carasvati books.

Leech, Geoffrey. 1993.Prinsip-prinsip Pragmatik.Jakarta:
Universitas Indonesia Press. Terjemahan M. D. Oka. 1983. The Principles of Pragmatics. London: Longman Group UK.

Sudaryanto. 1993. Metode dan Aneka Teknik Analisis Bahasa: Pengantar Penelitian Wahana Kebudayaan secara Linguistis. Yogyakarta: Duta Wacana University Press.

Sumardi' Mulyanto. 1974. Pengajaran Bahasa Asing Sebuah Tinjauan Dari Segi Metodologi. Jakarta: Bulan Bintang.

Syamsuddin AR, dkk. 2009. Metode Penelitian Pendidikan Bahasa. Bandung: PT. Remaja Rosdakarya.

Yule, George. 2006. Pragmatik. Yogyakarta: Pustaka Pelajar. Zamzani, dkk. 2010. Pengembangan Alat

Ukur Kesantunan Behasa Indonesia dalam Interaksi Sosial Bersemuka dan Non Bersemuka. Laporan Penelitian Hibah Bersaing. Tahun Kedua). (Yogyakarta: Universitas Negeri

Yogyakarta 
Jurnal Al Bayan Vol. 9, No. 1, Januari-Juni 2017.ISSN 2086-9282. e-ISSN 2549-1229 